\title{
Building capacity for green, just and sustainable futures - a new knowledge field requiring transformative research methodology
}

\author{
Eureta Rosenberg, Presha Ramsarup, \\ Sibusisiwe Gumede and Heila Lotz-Sisitka
}

\begin{abstract}
Education has contributed to a society-wide awareness of environmental issues, and we are increasingly confronted with the need for new ways to generate energy, save water and reduce pollution. Thus new forms of work are emerging and government, employers and educators need to know what 'green' skills South Africa needs and has. This creates a new demand for 'green skills' research. We propose that this new knowledge field - like some other educational fields - requires a transformative approach to research methodology. In conducting reviews of existing research, we found that a transformative approach requires a reframing of key concepts commonly used in researching work and learning; multi-layered, mixed method studies; researching within and across diverse knowledge fields including non-traditional fields; and both newly configured national platforms and new conceptual frameworks to help us integrate coherently across these. Critical realism is presented as a helpful underpinning for such conceptual frameworks, and implications for how universities prepare educational researchers are flagged.
\end{abstract}

\section{Introduction}

Focus on environment and sustainable development

In any given week a newspaper in South Africa is likely to feature a story demonstrating environmental issues as they manifest in various contexts. At the time of the 2015 conference of the South African Education Research Association (SAERA), the Mail and Guardian reported on the national drought (Kings, 2015, p.11). The town of Ficksburg had been without water for weeks. Rivers and boreholes had dried up and cattle was said to "paw at the dry crust of dams". South Africa was in the grip of the worst drought since 
the advent of democracy. Several Departments of Agriculture had declared disasters, and for the second season in a row, the maize crop would fail.

King's article demonstrated a key feature of environmental issues: they have social, economic and equity dimensions and often deep historical roots. The farmers who have been hit hardest by the drought, are those without the capital to weather consecutive crop failures, including the Black farmers who have only recently gained access to land denied by the 1913 Land Act. Also among the worst affected are the workers. In the 2008 drought, Warden township doubled in size with the influx of retrenched farm worker families.

Throughout the country, the most vulnerable members of society will suffer as the price of maize, and with it the cost of other basic foods, increases. Steeper food prices have been linked to social violence, and the Marikana massacre coincided with the sharpest increase in the price of white maize in history (African Centre for BioSafety, 2014).

Is the drought an environmental sustainability issue? On the one hand, dry spells have always characterised the region. Farmers supported by government have adapted, to a greater or lesser extent successfully, to the limitations of the known environment. But extreme weather conditions are predicted to worsen in southern Africa as a result of an anthropogenic environmental issue, enhanced global warming. For this and other reasons, traditional coping practices will no longer suffice. Environmental issues show up the shadow side of development (Beck, 1986). The previous government commissioned dams and inter-basin transfer schemes that benefitted White settlements and commercial farmers. Such engineering solutions have created new ecological and farming problems (e.g. black fly), and discriminated against the former homelands and subsistence farmers, who seldom benefited from the consequences of water being redirected to the privileged few. Dams and transfer schemes are not sustainable. All our major rivers have already been dammed, but not all households have access to water, and the Constitution compels us to share water with all, more widely and more equitably.

The National Water Act of 1998 (Republic of South Africa, 1998) advocated radically new (transformed) ways to manage and govern water, participatory decision-making about the allocation of water, and the need to maintain a minimum flow to sustain ecosystems. The Water Act is one of several national frameworks reflecting a commitment to environmental sustainability 
and economically inclusive development. Others include the National Development Plan (Republic of South Africa, 2011) and the Green Economy Accord (DED, 2011) between Labour, Business and Government, which commits to an equitable (inclusive of the poor), job intensive, low-carbon ('clean') and sustainable development path. All these suggest radically transformed work practices.

The notion of an inclusive green economy introduces a second important feature of environmental sustainability issues: besides 'doom and gloom', they also present opportunities for innovation and development. While limited rainfall is a fact of life, we can choose how we collect, use and share the water. South Africa's production systems are water inefficient, so there is room for improvement and innovation. We can also choose how we generate energy renewable energy alternatives to coal are fast coming on stream. We are in fact witnessing an eco-revolution (Montavaldo, 2009, cited in DEA, 2010) with technological advances to address environmental issues being made at an unprecedented pace, and at the same time, new development opportunities opening up.

Figure 1 shows three generations of eco-innovations, moving from end-ofpipe solutions to closed system or circular economy models in which radical resource productivity and sustainability is built into production and consumption systems from the start. This trend requires new models of process, new ways of thinking, new values and competencies, and therefore also new educational programmes, and new considerations for how to conduct educational research.

South Africa could take advantage of eco-innovations to create new work opportunities, including new work for those losing jobs as their enterprise becomes ecologically unsustainable. There are already more people employed in environmental and water related jobs in South Africa (800 000 at a conservative estimate) than in mining (DEA, 2010). A leading local study (Maia, Giordano and Kelder et al., 2011) indicated that South Africa could create jobs by investing in resource efficiency, sustainable transport and natural resource management, among others: "approximately 98000 new direct jobs, on average, in the short term, almost 255000 in the medium term and around 462000 employment opportunities in the formal economy in the long term" (p.12). 


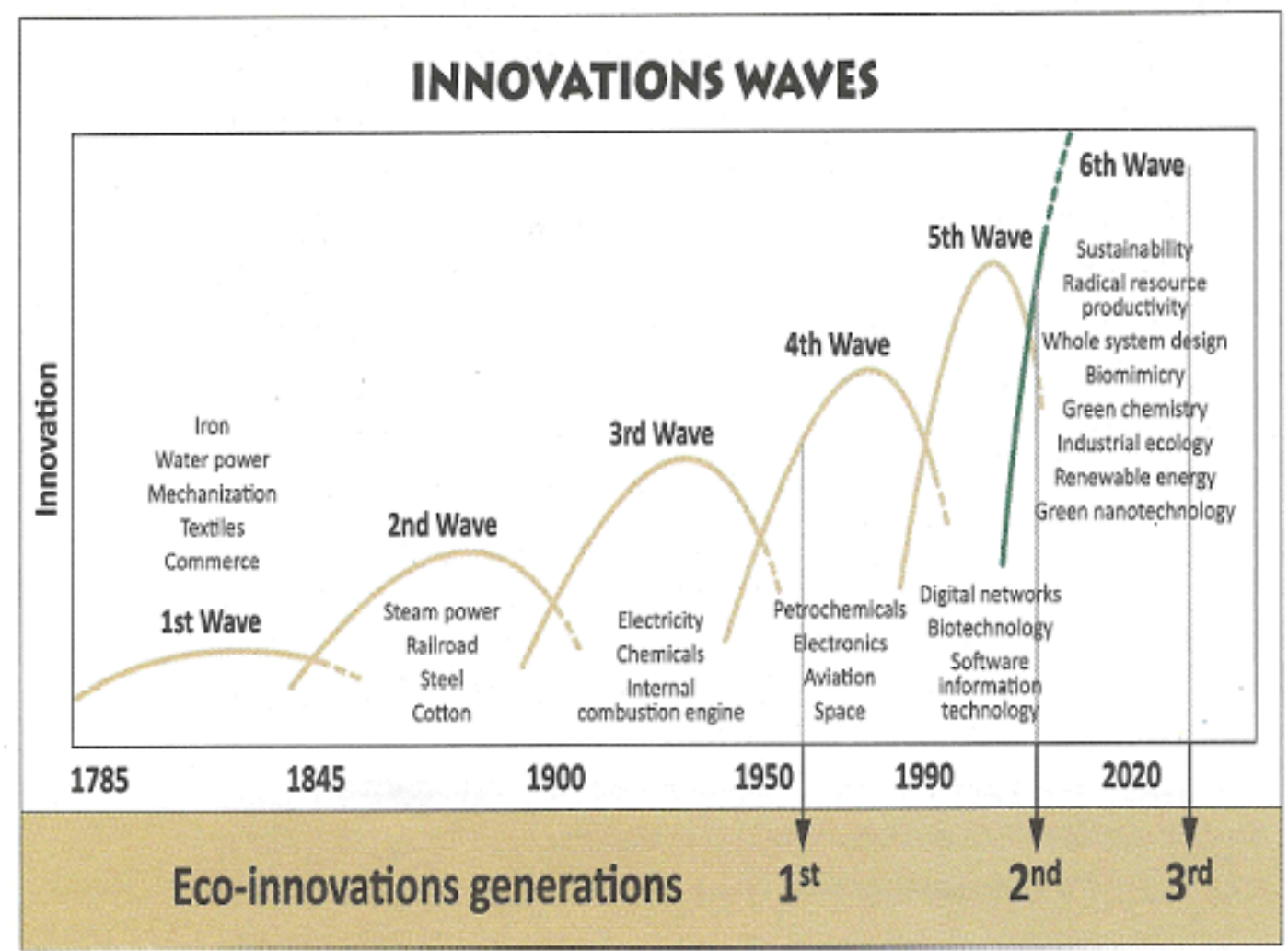

Figure 1: Over Time Innovations Respond to Environmental Opportunities and Lately, Risks (Montavaldo, 2009, in DEA, 2010) 
To drive eco-innovations, and to actualise the associated possibilities, a society needs people with a variety of skills which we can describe, for the sake of brevity, as 'green skills'. What are the implications for educators and for educational research?

The link to work, education and research

Around the world, new forms of work are emerging across sectors in response to climate change, renewable energy, biodiversity, waste and water demands, cleaner production and radical resource productivity (CEDEFOP, 2012). These include new 'green' occupations as well as new values, additional or different knowledge and competencies that would change traditional occupations either a little or a lot. For example, the National Water Act of 1998 created Catchment Management Agencies to make democratic and integrated, system-wide water resource management decisions. Today the Department of Water and Sanitation reports a shortage of people with catchment management skills - an occupation that did not exist 15 years ago. How does the education community respond to these developments? South Africa has world-class environmental policies, but few policy guidelines on how to decide what our green skills needs are, where they are needed, and how to develop them in our education and training sites. A study by the International Labour Organisation (ILO, 2011) showed that we compare poorly to other countries in this regard. The research for the Environmental Sector Skills Plan (DEA, 2010) found that South Africa's skills development system was largely re-active to the skills demands in the environmental sector. This makes a new educational knowledge field of green skills research an imperative. One of the first explorations in the field should be: How, in the absence of policy guidelines, should educational researchers approach such research?

Answering this question requires a fuller response than we can give here, but part of our answer is that 'green skills' research requires a transformative methodology. That is, we need research methods, and underpinning theory guiding the choice and use of those methods, that help to bring about deep and radical cultural and institutional shifts, as opposed to surface reform (Popkewitz, 1991). This need for transformation is, we believe, shared by other educational research fields. Our argument may therefore be relevant to educational researchers generally. In the next sections we explore some 
features of this emerging knowledge field, why its methodology needs to be transformative, and what a transformative approach might entail. (The implications for curriculum will be more implicit, and the subject for a followup paper to be presented at SAERA 2016.)

First we continue the analysis of environmental issues started in the introduction, and then draw insights from reviews of recent 'green skills' studies. This includes a pioneering review conducted by Rhodes University with the South African Qualifications Authority (SAQA) in a research programme on change-oriented workplace learning and sustainable development practices, aimed at understanding learning pathways across the National Qualifications Framework landscape (Lotz-Sisitka, 2014). A second review of the new knowledge field was undertaken in a National Research Foundation (NRF) supported project. The SAQA and NRF supported work is in turn informing a programme funded by DEA's Green Fund through the Development Bank of Southern Africa, aimed at strengthening the national system to plan for the green skills South Africa needs (see www.greenskills.co.za). As part of this programme, a number of participating researchers presented early insights at SAERA 2015, and invited comments from the broader educational community to help strengthen the emerging field. This paper builds on the interactions at SAERA 2015.

\section{Why transformative?}

We start by tracing the contours of the environmental crisis, to demonstrate that it requires a strong transformative agenda. Far from being a peripheral concern, the environment brings important additional perspective to bear on older research questions regarding development, capabilities, economic inclusivity and social justice.

The notion 'green' has become a symbol for the response to the environmental crisis, but facets of the crisis are not only green (literally or figuratively): they involve biodiversity on land, but also the protection of the oceans, freshwater and air quality ('blue' considerations), waste management and cleaner production ('brown' issues), the food value chain and more. While the risks of enhanced global warming (also termed climate change) are now widely known, the loss of species is, based on scale alone, an even bigger planetary issue, as is the build-up of nitrates in freshwater systems 
(Rockström, Steffen and Noone et al., 2009, see Figure 2). Other issues, such as the levels of chemical pollution on the planet, have not even been quantified. Based on what we do know, scientists argue that while humans are inventive and have achieved major feats, our home planet has physical and ecosystem boundaries beyond which we should not attempt to develop; that we have already raced past four of the known nine 'planetary boundaries', and that this calls society to find a radically new development path.

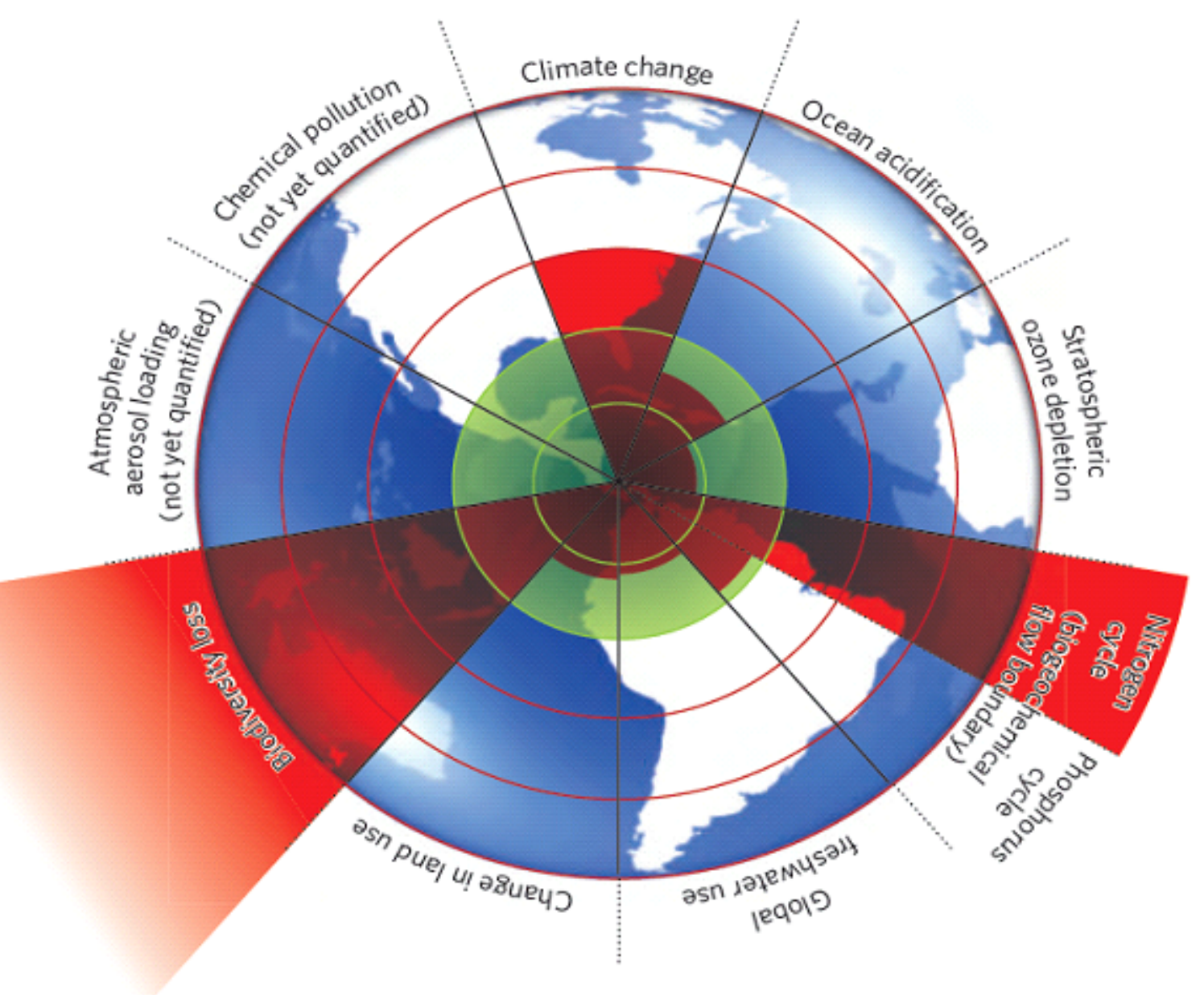

Figure 2: Planetary issues are boundaries for development and well-being (Rockström et al., 2009) 
The notion that humanity is facing a crisis of its own making is not new. A report on planetary 'limits to growth' (Meadows, Meadows, Randers and Behrens, 1972) was commissioned by the Club of Rome in 1972. A decade earlier, Carsons (1962) wrote Silent Spring, a small book on the impact of pesticides on song birds. Silent Spring was included in Castro's list of classic revolutionary readings for Cuban students (Robin, Sorlin and Warde, 2013). This may seem surprising, as Western-based reports like Limits to Growth have been critiqued for being neo-Malthusian and blind to the fact that many have never tasted the fruits of modern development (ibid). Castro linked environmental destruction in Cuba to global inequalities, arguing that "unequal terms of trade, protectionism, and the foreign debt assault the ecology" and that "If we want to save mankind from this self-destruction, we have to better distribute the wealth and technologies available in the world" (Castro, 1992). Many scholars from the Global South and North have argued that the same political decisions, economic models and cultural frameworks that lead to environmental damage, also cause, perpetuate or fail to solve poverty, unemployment and inequality. (See e.g. Development as planned poverty, by Illich, 1971; Science, nature and gender, by Shiva, 1989; The making and the unmaking of the third world by development, by Escobar, 1995; The idea of progress, by Shanin, 1997; and The Jo'Burg Memo: Fairness in a Fragile World, by Sachs, 2002). These problems are also described at a local level in the Department of Science and Technology's Global Change Grand Challenge National Research Plan (DST, 2010). Dussel (1998) explained the problematique as constituted by three major intersecting limits:

1) Ecological destruction of the planet based on a view of nature as an exploitable object

2) Poverty and inequality based on exploitation and accumulation of wealth

3) Narrow rationalities epitomized by colonial and imperialist thinking (Dussel, 1998).

Deepening this analysis, De Sousa Santos (2014) argued that modern Western forms of thinking and policy-making involve mainly a dualist Cartesian logic, and that, in an example of a drive for transformation that has epistemic dimensions, "social movements [have] . . been organizing their struggles on 
the basis of a non-Eurocentric conception of the relation between nature and society" (p.23).

Environmental sustainability has come to be seen as part of a 'polycrisis' (Morin, 1999), a situation in which there is not one single big problem, but rather a series of overlapping and interconnected problems, all with multiple dimensions. Addressing such intertwined problems, with their deep roots in pervasive cultural models and myths of economic growth and progress, presents huge educational challenges. The Millennium Ecosystem Assessment (2005) pointed out that while human societies have succeeded in radically changing ecosystems, we have great difficulty in changing the social systems through which we use and affect these ecosystems. This could well be because the polycrisis is both physical and ontological in nature (in the breach of planetary boundaries) and epistemic, in that it requires new forms of thinking and new ways of generating knowledge. This points to implications for education and educational research.

\section{Transformative methodology for green skills research}

The kinds of knowledge, values and skills needed to address environmental sustainability in the context of the polycrisis requires transformative approaches to learning and education. Scholars like Orr (1992) Lotz-Sisitka, Wals, Kronlid and McGarry (2015) are among the many who call for new approaches to curriculum and pedagogy in order to respond adequately to social-ecological issues. Their call has been taken up in international movements like the United Nations Decade of Education for Sustainable Development (UNESCO, 2014). Governments and education providers have responded, in the form of new environmental content being introduced into basic and higher education curricula, and new qualifications, but also through a reorientation of pedagogy, for example leadership courses that foster social learning (as opposed to teaching doctrines) by bringing leaders from different fields together to work on 'change projects' that address social-ecological issues (e.g. Scharmer, 2009). Universities around South Africa, too, have started to develop not only new environmental content and courses, but also new forms of pedagogy including inter-disciplinary programmes on socialecological sustainability, at under-gradate and post-graduate levels, and social learning programmes involving groups of learners whose occupations require 
them to work together, across disciplines and levels, towards achieving environmental sustainability.

The work of Beck (1986), Wals (2007) and Scharmer (2009), among others, lead us to suggest that in order to achieve the deep changes required, global and local communities, industries and individuals need to engage in conscious and collective reflexive processes, in social learning to search together for new answers. The intellectual project associated with this reflexive, learningthrough-doing-and-reflection process is in some ways in its infancy. In 2015 the NRF invested in a South African Research Chair Initiative (SARChI) at Rhodes University, to advance this educational field by exploring social learning in both formal institutional and informal community settings. This work includes an exploration of the conceptual and educational planning frameworks required to prepare South Africans for new forms of work thatbecome necessary to both transform systems, and to work in transforming systems of production, governance and education.

Course, curriculum and qualification planning, and broader planning and development for new skills needs, must be guided by research that informs providers, funders and prospective learners what work and associated skills are needed by society and employers; and what skills South Africa is currently developing and utilising, or failing to develop and utilise, and why.

This paper is an early exploration of how to approach such research. (Elsewhere, we will further explore curriculum implications.) In reflecting on the studies reviewed for the NRF New Knowledge Field project, we noted that if we frame our research only in terms of traditional methodologies, we may be trapped in viewing a problem through the same lenses that created it; and the new knowledge produced may fall short of a transformative intent. At the SAERA 2015 panel discussion we therefore asked the following questions:

How do we perform transformative research that effectively responds to the need for ecological sustainability and social equity? and

When we research education and work, how do we avoid the trap of an economistic framework for post-school research? 
In the remainder of the paper, we elaborate our argument that transformative research methodology is required, and explore what this might mean for research processes, planning and design, and curriculum for educational research capacity development. To do so we draw on the comments received at SAERA 2015, our experience as educational researchers, the studies reviewed in the NRF and SAQA projects, the development critiques outlined above, and on critiques of the links between economy, development, employment and skills (Allais and Nathan, 2012; Hugo, 2015).

Green skills research requires diverse disciplines or knowledge fields

Given that sustainability issues manifest as a 'polycrisis' with social and ecological dimensions, sustainability research draws on multiple disciplines that span the social, natural and earth sciences as well as knowledge fields outside the disciplines. We work in boundary crossing spaces in which the knowledge bases of development, environment, agriculture and water management also overlap with the knowledge bases of adult and basic education, workplace-based learning and social justice theory, for example. Researchers in this space may need to draw on non-traditional fields, and to bring fields of practice and intellectual traditions together in unusual combinations.

Methodological considerations flowing from this include the following:

- To work across knowledge fields, researchers must take particular care to define concepts so that they can be used with clarity and consistency by participants from diverse backgrounds. Key concepts that require clarification for green skills research include: skill (a term used in diverse ways in the national system), green economy, and green jobs. Given that green skills research findings are required in diverse contexts (academia, workplaces, industry bodies and Sector Education and Training Authorities, among others), we may also need to clarify what we mean by research.

- In addition to drawing on different knowledge fields, we need conceptual frameworks that help research teams to integrate across these fields, and make the most of their diverse strengths, rather than subsume some disciplines into others. Conceptual frameworks are required to help us design studies that allow for coherence and are also 
intellectually and practically generative. This suggests a transdisciplinary (as opposed to a multidisciplinary) approach with conceptual and design frameworks that are new to all disciplines. At a conference of the Programme on Ecosystem Change and Society, Lotz-Sisitka (2015) and Preizer (2015) interrogated the need for a 'third space' when researching in the transdisciplinary and social-ecological realm.

- It is not only necessary to be conceptually clear and define the concepts we work with, we may also need to be conceptually critical and creative, and on occasion re-define concepts from the established norms. This point is elaborated next.

\section{Green skills research requires new conceptual frameworks}

Linked to the need for a transdisciplinary approach, is the need to re-think some concepts rather than to uncritically adopt standard definitions from their respective fields of origin. We need new concepts to better understand emerging and old issues, particularly complex, intractable social-ecological problems that are so 'wicked' (Rittle and Weber, 1973) that we need new lenses on them. An example is the issue of graduate unemployment observed in the same field that skills shortages are experienced. Scholars like Hugo (2015) and Allais and Nathan (2012) argue that we need to re-think the conventional coupling of education and employment, and re-think the role of the economy in these.

This need to conceptually re-frame and re-define applies to educational concepts like 'skill' and to economic concepts like 'growth', 'market' and 'demand'. In preparing the Environmental Sector Skills Plan (DEA, 2010) and the Biodiversity Human Capital Development Strategy (SANBI and the Lewis Foundation, 2010), green skills researchers found that employers would not necessarily register or report a 'demand' for a particular skill to Sector Education and Training Authorities, if they are not at that time advertising for new staff to fill such positions, even though their own staff, or environmental groups and civil society watchdogs may have identified a need for such skills. This was also noticeable in a study on green skills for mining (Rosenberg. Togo, Ramsarup and Maphinyane, 2015) The notion of 'demand' based on a 'market' for skills therefore requires a re-think. The fact that there 
is not a (paying) market for a particular skill does not mean that there is no need or demand beyond the market. Environmental concerns are public concerns, related to the common good, and cannot always be quantified in privatised or economic terms. In this regard, participants in the NRF project as well as the SAERA panel discussion noted that it may be more useful to make the departure point for green skills studies 'green work', rather than 'green jobs'.

The concept of 'green economy', central in many green skills studies, provides another example of the need to interrogate frequently used concepts. UNEP has defined the green economy as "one that results in improved human wellbeing and social equity, while significantly reducing environmental risks and ecological scarcities. It is low carbon, resource efficient, and socially inclusive" (UNEP, 2011).

The UNEP definition is useful in that it highlights the considerations of social justice and inclusivity, which are absent from some definitions of the green economy, but its approach to development can be questioned, in that it advances the idea of 'resource scarcity' as a key consideration. Other approaches to development (described e.g. by Norberg-Hodge, 1997) posit that humanity has abundant natural resources at its disposal, provided we make wise development decisions. For example, the sun is a practically limitless source of energy; and water and nutrients cycle endlessly within planetary boundaries. In such a framing, one would not wait for resources like water or coal to become scarce, before switching to alternatives. Green skills research should be cautious of taking conventional concepts like 'scarcity' at face value, and at least consider both resource scarcity, and the potential to switch to ecologically sustainable alternatives even in the absence of scarcity, as drivers for skills demand.

Green skills research must consider non-formal and unconventional contexts

Social-ecological sustainability issues entail complex problems and solutions that lie at least partly, and often predominantly, in the socio-political arena. Learning to address these problems is seldom a mere transfer of expertise and technical knowledge; the knowledge required is often yet-to-be-developed, and most suitably constructed in the process of collectively working on 
solutions (see Scharmer, 2009; Wals, 2007). Thus communities in all spheres (government, industry and civil society) need social learning (Wals, 2007) to respond to sustainability issues. This also pertains to formal education. Social learning should not be seen as parallel to, or separate from formal learning, but as an integral part of new approaches to formal learning, which in turn requires a re-orientation of formal education practices. This has implications for academic programme developers. For educational researchers interested in curriculum and skill 'supply', the implication is that they may need to explore beyond formal qualifications and training opportunities for green skills development. This was evident in a study by Ramsarup (see Ramsarup and Lotz-Sisitka, 2014) who found that environmental engineering learning pathways consisted of a complex mix of formal and social learning developed through an equally complex employment mix, in which specialization occurred through iterative movement between environmental and engineering organisations.

In determining the supply of and demand for green skills, researchers also need to consider green work that is not (yet) paid for by established markets. Examples are rural people who maintain communal wetlands through traditional practices; township food gardeners who keep children healthy with their produce; or the thousands of former miners who could potentially restore abandoned mine sites to ecological health. Narrow formal definitions of 'skills' as adopted in the National Qualifications Framework have 'de-skilled' some people (Terreblanche, pers. comm., 2015). This comes about because existing skills (such as wetland maintenance) are deemed value-less within a dominant economic framework that tends to disregard work for the social good (such as community health, environmental integrity) as having value - a practice linked to the exclusion of environmental and social resources in mainstream economic reckoning (ibid). Green skills researchers may need to consider social innovation outside the mainstream, as well as traditional and local knowledge. How indigenous and local knowledge and associated skills pertain to problems like extreme weather events, food and water insecurity, and pollution, could be related research questions. (For epistemological considerations from a critical realist perspective, see Price, 2016).

Green skills research needs to be generative

Most educational researchers want to see their work resulting in change. But 
in general, many studies remain unused. Much has been written about the reasons for this, which include an over-reliance on scholastic reasoning (Bourdieu, 1984) which dis-embeds knowledge from practice, creating often abstract research products or outcomes which are difficult to re-embed in society. This problem is often expressed in terms of:

- Poor communication of research outcomes

- the research process excluding potential users

- the failure to address the questions potential users are actually asking, or

- $\quad$ findings not being powerful enough to guide potential users.

To address this, many researchers in the late 1980s and 1990s departed from what Popkewitz (1991) called an R-D-D-A approach to knowledge production (research-design-disseminate-adopt) and embraced participatory and action research methods (e.g. Carr and Kemmis, 1986, in the context of researching teacher professional development).

While participatory and action based studies may involve relevant stakeholders, they do not, in our experience, always result in useful knowledge. Daniels and Sannino (2009) speak of the generative power of research that is designed so that it allows for meaning making amongst those involved in the research process, and for the emergence of agency for change. They see research as a process of expansive social learning. The generative potential of research may lie not only in the way the research is conducted, but also in the chosen ontological and epistemological frameworks. Engeström and Sannino (2010) suggest that activity theory gives research generative power, because it provides both a strong theory for understanding human activity (in complex contexts) and a related, productive method for studying human activity. Activity theory is generative because it produces knowledge explaining socio-culturally and socio-materially shaped conditions and experiences, and from this, anticipatory and emergent possibilities and predictions, which can inform practical decision-making in complex situations. In many social sciences including educational fields, researchers have chosen interpretivist and small scale surveys or case studies as they abandoned the practice of forcing inappropriate empiricist natural science methods onto social situations. As argued by Pawson and Tilley (1997), small scale case studies can lack the power to adequately explain, generalise and predict social realities. The implicit critical realism which underlabours activity theory (Nunez, 2013) offers a powerful alternative. Below we propose 
that critical realist perspectives on emergence and transformative praxis might well be useful in making green skills research generative and therefore, give it the power to be transformative.

Green skills research must explore multiple layers with mixed methods

Like other social contexts, green skills contexts have features that are empirical, constructed and actual - all of which are real (Sayer, 2000). Whether a particular skill is scarce or not, is a social construct, over which there may be various opinions, and which may or may not be empirically reported. But whether we have access to and utilise certain skills or not, does have a very real impact on our environment (e.g., when we increase water supplies by clearing invasive alien vegetation, or decrease water supplies by failing to maintain sewage works).

To capture all these real dimensions of green skill matters (empirical, perceived and actual), researchers could draw on laminated methodologies that explore various layers of reality through mixed methods such as small scale case studies and larger scale surveys, and analyse across them. A critical realist underpinning encourages the use of multiple methods (Sayer, 2000) and makes it possible to work generatively with them. For example, it allows for generalisation from the case (such as the individual career path or workplace) to the whole or wider system (Pawson and Tilley, 1997; Sayer, 2000, drawing on the work of Bhaskar (usefully re-articulated in Bhaskar, 2010)).

Green skills research topics span access to study and work (e.g. Gumede, 2015); the learning and career pathway experiences in workplaces and educational institutions (e.g Madiba, 2016 and McKrill, 2015); the transitions individuals make between different levels and parts of the system (e.g. Dotwana, 2015, Ramsarup and Lotz-Sisitka, 2014), the features of the social, political and institutional contexts that shape the skills that learners acquire (see e.g. Olvitt, 2015), and the macro-economic and system wide drivers that determine skills demand (e.g. Rosenberg et al., 2015). 
These research areas require a consideration of the micro-level (of the individual transitioning through work and learning) as well as the macro level (society or economy wide) and meso levels (sector, community, organisation) in-between. Many of the listed studies therefore feature multi-levelled system analyses. An example is the framework in Figure 3, which was adapted from international guidelines (CEI, 2011) and comprises the multiple levels that were considered in order to determine the demand for green skills in mining in South Africa, and associated supply challenges (Rosenberg et al., 2015).

There is also a need to understand the interplay between individual choices and options, and wider systems and structures, reflected in Figure 3 with an arrow indicating analysis applied iteratively between the levels. The review of the listed studies (Lotz-Sisitka, 2014) suggests that the articulation or misarticulation or alignment and transitioning between systems can be particularly important (for example school subject choices that prevent transitioning into a favoured environmental career). Lotz-Sisitka, Mohanoe, Ramsarup and Olvitt (2012), drawing on the work of Fenwick, Edwards and Sawchuk (2011), called for attention to boundary making processes in the skills development system, and boundary crossing processes. Failure to activate these maintains 'lock-in' problems and absences. For transformative potential, it therefore seems critical that research explores both the connections and emerging connections between macro, meso and micro levels or different spheres of the skills ecosystem; and the absences that impede transitions and emergence. 
Micro-Economic \& Social-Ecological (Drivers of demand)

- Developments, events, trends and forecasts

- Policy, incentives, regulatory frameworks

Sector, System \& Landscape level (Demand)

- New technology and development planning

- Policy, incentives, frameworks

Occupations and Skills (Niche level)

- Value chains, functions, classification, career pathways

- Skills: Scarce skills, critical/generic skills, top up skills

Learning Pathways, Training and Education (Supply)

- Learning pathways, qualifications, articulation

- Providers, curricula, standards

Transitioning into Work (Individuals)

- Career guidance, workplace-based learning, professional developments

Figure 3: A multi-levelled framework for green skills research (Rosenberg et al., 2016) 
In search of a transformative methodology, the South African green skills studies listed here drew on a critical realistic laminated epistemological framework (Bhaskar, 2010; Sayer, 2000) and a critical realist dialectic (Bhaskar, 1993; Norrie, 2010). As methodological framings these allow for the explanation of emergence via generative mechanisms, showing an interconnected 'constellation' of activity and emergence in the skills development landscape (Lotz-Sisitka, 2014). They allow research to engage both macro and micro level features in an open systems perspective, that considers not only what is, but also what is absent; what is possible and what can be done (Bhaskar, 1993, 2010). For example, what can be done to pay for or produce the green work and associated skills needed by society? Norrie (2010) argued that absence is critical to a transformational intent: that change lies in the absenting of absences, and in absenting the structural constraints that keeps an absence in place. Examples of absences identified, for example by Ramsarup and Lotz-Sisitka (2013), are inadequately differentiated green occupations on the National Organising Framework of Occupations (OFO), and the lack of qualifications for environmental technicians, both of which present constraints: for individuals to access paid green work and for South Africa to achieve the promise of the green economy.

Finally, skills strategy research conducted by Rhodes (DEA, 2010) and the Human Sciences Research Council (HSRC, 2009) highlighted the need for meta-analyses and national data, to allow for wider analysis across studies in order to give green skills research adequate generative and transformative power. This will only be possible if the systems, platforms and frameworks for collating research across institutions and contexts exist. This means, inter alia, that environmental occupations are included and adequately differentiated in the OFO and in Statistics SA and labour market surveys. The Department of Higher Education and Training's Research Repository managed by the Labour Market Intelligence Partnership has potential for analysis across studies, provided adequate conceptual frameworks are used to strengthen the intellectual project of coordination. Multiple-field platforms like SAERA are also highly significant in this regard, as they allow for both rigour and crosspollination through diversity.

\section{Conclusion}

In this paper we proposed that green skills research requires a transformative 
approach to research methodology. Based on the studies we reviewed we considered how a transformative methodology might be considered in green skills research framings, processes and design. We conclude that:

- Green skills research involves diverse disciplines and knowledge fields, and the methodology should consider a transformative transdisciplinary or meta-approach, rather than merely drawing on fields or specialists in an additive multi-disciplinary approach. This has implications for the curricula of programmes to develop educational research capacity.

- Green skills research requires strong attention to defining concepts and a critical interrogation of mainstream definitions which may perpetuate framings that are part of the problem we are trying to re-search.

- In studying green work and skills, researchers should also consider unconventional contexts where environmental work may be needed, not only the conventional workplace as site of employment and skills deployment, and transformative approaches to learning in both formal and non-formal settings.

- Green skills research needs to be generative and to this end, both narrow positivist methodology and small-scale interpretive studies have limitations; critical realist approaches point the way to research that has enough veracity to guide real world policy and decision making.

- Green skills research needs to study multiple layers of reality with mixed methods and integrative frameworks to bring findings from across the layers together in meaningful and transformative syntheses, that allow for a grasp of emergence and for transformative praxis.

- A national platform and robust intellectual leadership are needed to build new knowledge from a growing number of green skills studies. Coordination lies not just in bringing these researchers together, but in stimulating engagement with ideas such as those posed in this paper. 


\section{References}

African Centre for BioSafety. 2014. GM Maize, Lessons for Africa, p.23, , www.acbio.org.za, quoting Bar-Yam, Y., Lagi, M., Bar-Yam, Y. 2013. South African riots: repercussion of the global food prices and US drought.

Cambridge: New England Complex Systems Institute.

Allais, S.M. and Nathan, O. 2012. Skills, What skills? Jobs, What jobs?

Overview of studies examining relationships between education and training and labour markets. Paper prepared for the DHET Labour Market Intelligence Partnership. Accessed in June 2015 from

http://www.academia.edu/1780000/Skills What Skills Jobs What Jobs

Beck, U. 1986, translated in 1992. Risk society. Towards a new modernity. London: Sage.

Bhaskar, R. 1993. Dialectic. The pulse of freedom. London: Verso.

Bhaskar, R. 2010. Contexts of interdisciplinarity: interdisciplinarity in climate change. Chapter 1. In Bhaskar, R., Frank, C., Høyer, K.G., Naess, P. and Parker, J. (Eds). 2010. Interdisciplinarity and climate change: transforming knowledge and practice for our global future. London: Routledge.

Bourdieu, P. 1984. Homo Academicus. Cambridge: Polity.

Carr, W. and Kemmis, S. 1986. Becoming critical. Education, knowledge and action research. London: Routledge.

Carsons, R. 1962. Silent Spring. Boston: Houghton Mifflin.

Castro, F. 1992. Speech by Cuban President at the United Nations Conference on Environment and Development, in the Riocenter Conference Hall, Rio de Janeiro. Accessed January 2016 from http://lanic.utexas.edu/project/castro/db/1992/19920612.html.

CEDEFOP (European Centre for the Development of Vocational Training). 2012. Green skills and environmental awareness in vocational education and training. Synthesis report. Luxembourg: European Union. 
CEI (Centre for Employment Initiatives). 2011. A summary of methods and approaches for identifying the skills needs and approaches associated with the transition to a low carbon economy and a consideration of the policy and research implications. Accessed in July 2014 from www.cei-international.org

Daniels, H. and Sannino, A. Foreword. In Daniels, H, Sannino, A. and Guttierez, K.D. (Eds). 2009. Learning and expanding with activity theory. Cape Town: Cambridge University Press.

DEA (Department of Environmental Affairs). 2010. Environmental sector skills plan for South Africa. A systems approach to capacity development. Pretoria: DEA.

DED (Department of Economic Development). 2011. New growth path: Accord 4. Green Economy Accord. Cape Town: DED.

De Sousa Santos, B. 2014. Epistemologies of the South. Justice against epistemicide. London: Verso.

DHET (Department of Higher Education and Training). 2011. National skills development strategy iii. Pretoria. Accessed in December 2011 from skillsportal.co.za.

DST (Department of Science and Technology). 2010. Human capital development strategy for the global change national research plan. Pretoria: DST.

Dotwana, A.Z. 2015. The factors that constrain or enable black female Botany and Zoology Honours students in making the transition to Masters studies in Eastern Cape universities. MEd thesis. Grahamstown: Rhodes University.

Dussel, E. 1998. Beyond eurocentrism: the world-system and the limits of modernity. In Jameson-M.Miyoshi, F. The cultures of globalization. Duke University Press: Durham, pp.3-31.

Engeström, Y. and Sannino, A. 2010. Studies of expansive learning: foundations, findings and future challenges. Educational Research Review. doi:10.1016/j.edurv.200212.002. 
Escubar, A. 1995. The making and unmaking of the third world through development. Chapter 8. In Rahnema, M. and Bawtree, V. (Eds). 1997. The post-development reader, pp.85-93. London: Zed.

Fenwick, T., Edwards, R. and Sawchuk, P. 2011. Emerging approaches to educational research: tracing the socio-material. London: Routledge.

Gumede, S.M. 2015. Investigating educational elements that contribute towards access and transitioning into and within the Green Economy in South Africa: a case of educationally marginalised youth in the Eastern Cape and KwaZulu-Natal. PhD proposal. Grahamstown: Rhodes University.

HSRC (Human Sciences Research Council). 2009. Guidelines towards a Human Capital Development Strategy in the biodiversity sector. Pretoria: HSRC.

Hugo, W. 2015. Consuming our children. The future of education. Keynote address at transformative environmental learning, schooling and teacher education, the $25^{\text {th }}$ Anniversary of the Environmental Learning Research Centre, 14 October 2015. Grahamstown: Rhodes University.

Illich, I. 1971. Development as planned poverty. Chapter 11. In Illich, I. 1971. Celebration of awareness. London: Marion Boyars.

ILO (International Labour Organisation). 2011. Skills for green jobs: a global view. Synthesis report based on 21 country studies. Geneva: International Labour Office, Skills and Employability Department, Job Creation and Enterprise Development Department.

Kings, S. 2015. Parched Free State hit by mass exodus. Mail and Guardian, 16-22 October, p.11.

Lotz-Sisitka, H. 2014. Change-oriented workplace learning \& sustainable development practices Phase 2: understanding learning pathways and systems of work and learning across the NQF landscape. Phase 2 (6th) and Semi-Final Research Report. Rhodes University/SAQA Research Partnership.

Grahamstown: Rhodes University Environmental Learning Research Centre. 
Lotz-Sisitka, H. 2015. Transdisciplinarity and learning. In a session on Interrogating a third space: what methods are appropriate for understanding social-ecological systems? At the PECS (Programme on Ecosystem Change and Society) conference, 5 November 2015. Spier: PECS.

Lotz-Sisitka, H., Mohanoe, N., Ramsarup., P. and Olvitt, L. 2012. Boundary making and boundary crossing in learning pathways access and progression: voices from the workplace. Paper 3. Rhodes University/SAQA Research Partnership. Grahamstown: Rhodes University Environmental Learning Research Centre.

Lotz-Sisitka, H.B., Wals, A.E.J., Kronlid, D. and McGarry, D. 2015. Transformative, transgressive social learning: rethinking higher education pedagogy in times of systemic global dysfunction. Current Opinion in Environmental Sustainability, 16: pp.73-80.

Madiba, M. 2016. An investigation of the role of training and organisational support to strengthen GIS interns' participation in workplace occupations: a case study of the Groen Sebenza internship programme. MEd thesis. Grahamstown: Rhodes University.

Maia, J., Giordano, T., Kelder, N., Bardien, G., Bodie, M.; Du Plooy,P., Jafta, X., Jarms, D., Kruger-Cloete, E., Kuhn, G, Lepelle,R., Makaulule.L., Mosoma,K., Neoh, S., Netshtomboni, N., Ngozo, T., Swanepoel, J. 2011. Green jobs. An estimate of the direct employment potential of a greening South African economy. Pretoria: Industrial Development Corporation, Development Bank of Southern Africa and TIPS (Trade and Industrial Policy Strategies).

McKrill, L. 2015. An investigation of enabling and constraining factors affecting the supply and demand of specific biodiversity scarce skills to the biodiversity sector. MEd thesis. Grahamstown: Rhodes University.

Meadows, D.H., Meadows, L. Randers, J. and Behrens, W.W. 1972. The limits to growth. New York: Universe Books.

Millennium Ecosystem Assessment. 2005. Ecosystems and human wellbeing : Synthesis. Washington, DC: Island Press. 
Mohanoe, N. 2013. Learning pathways of key occupations relevant to sustainable development in Makana municipality. MEd thesis. Grahamstown: Rhodes University.

Morin, E. 1999. Homeland earth. London: Hampton.

Norberg-Hodge, H. 1997. Learning from Ladakh. Chapter 2. In Rahnema, M. and Bawtree, V. (Eds). 1997. The post-development reader, pPp.22-29. London: Zed.

Norrie, A. 2010. Dialectic and difference: dialectical critical realism and the grounds of justice. London: Routledge.

Nunez, I. 2013. Critical realist activity theory: an engagement with critical realism and cultural-historical activity theory. London: Routledge.

Orr, D. 1992. Ecological literacy: education and the transition to a postmodern world. New York: SUNY.

Pawson, R. and Tilley. N. 1997. Realistic evaluation. London: Sage.

Popkewitz, T.S. 1991. A political sociology of educational reform.

Power/knowledge in teaching, teacher education, and research. New York:

Teachers College.

Price, L. 2016. Using retroduction to address wicked problems. Chapter 7. In Naess, P. and Price, L. (Eds). 2016. Crisis system. A critical realist and environmental critique of economics and the economy.. London: Routledge, pp.109-129.

Ramsarup, P. and Lotz-Sisitka, H.B. 2013. Understanding the absence of parallel learning pathways: the missing 'middle track' in the environmental sector. Paper 4. Rhodes University/SAQA Research Partnership.

Grahamstown: Rhodes University Environmental Learning Research Centre.

Ramsarup, P. and Lotz-Sisitka, H. 2014. Learning and transitioning in boundaryless work: the case of the environmental engineer. Paper 6. Rhodes University/SAQA Research Partnership. Grahamstown: Rhodes University Environmental Learning Research Centre. 
Republic of South Africa. 1998. National Water Act, Act No.36 of 1998. Pretoria: Department of Water Affairs.

Republic of South Africa. 2011. National Development Plan. Vision 2030. Pretoria: Office of the Presidency.

Rittle, H.W.J. and Webber, M.M. 1973. Dilemmas in a general theory of planning. Policy Sciences, 4: pp.155-167.

Robin, L., Sorlin, S., and Warde, P. 2013. The future of nature: documents of global change. New Haven: Yale University Press.

Rockström, J., W. Steffen, K. Noone, Å. Persson, F. S. Chapin, III, E. Lambin, T. M. Lenton, M. Scheffer, C. Folke, H. Schellnhuber, B. Nykvist, C. A. De Wit, T. Hughes, S. van der Leeuw, H. Rodhe, S. Sörlin, P. K. Snyder, R. Costanza, U. Svedin, M. Falkenmark, L. Karlberg, R. W. Corell, V. J. Fabry, J. Hansen, B. Walker, D. Liverman, K. Richardson, P. Crutzen, and J. Foley. 2009. Planetary boundaries: exploring the safe operating space for humanity. Ecology and Society 14(2): p.32. [online] URL: http://www.ecologyandsociety.org/vol14/iss2/art32/

Rosenberg, E., Togo, M., Ramsarup, P. and Maphinyane, A. 2015. Green skills for mining. Unpublished study for the Mining Qualifications Authority. Grahamstown: Rhodes University Environmental Learning Research Centre. SANBI (South African National Biodiversity Institute) and the Lewis Foundation. 2010. Biodiversity Human Capital Development Strategy. Accessed in March 2015 from www.greenmatter.co.za.

Sayer. A. 2000. Critical realism and social science. London: Sage.

Sachs, W. The Jo'burg memo: fairness in a fragile world. Memorandum for the World Summit on Sustainable Development. Berlin: Heinrich B?11 Foundation.

Scharmer, O. 2009. Ten propositions on transforming the current leadership development paradigm. Paper prepared for the Round Table Meeting on Leadership for Development Impact, The World Bank. The World Bank Institute Washington, DC. September 27-28, 2009. Accessed in January 2016 from http://www.ottoscharmer.com/sites/default/files/2009_FieldBasedLeadDev.pdf 
Shanin, T. The idea of progress. 1997. Chapter 6 in Rahnema, M. and Bawtree, V. (Eds). 1997. The post-development reader. London: Zed, pp.65-71.

Shiva, V. 1989. Science, nature and gender. Chapter 2 in Shiva, V. 1989. Staying alive: women, ecology and development. London: Zed.

Terreblanche, C. 2015. Personal communication at the NRF New Knowledge Field Green Skills Research Seminar, Centre for Researching Education and Labour, Wits University, 11 June 2015.

UNESCO (United Nations Educational, Scientific and Cultural Organisation). 2014. UN Decade of education for sustainable development 2005-2014. The DESD at a glance. Accessed in January 2016 from http://unesdoc.unesco.org/images/0014/001416/141629e.pdf.

UNEP (United Nations Environmental Programme). 2011. Towards a green economy: pathways to sustainable development and poverty eradication.

Accessed January 2016 from http://www.unep.org/greeneconomy/GreenEconomyReport/tabid/29846/Defau $\underline{1 t . a s p x}$

Wals, A.E.J. 2007. Social learning towards a sustainable world. Principles, perspectives, and praxis. Wageningen: Wageningen Academic Publishers. 
Eureta Rosenberg

Rhodes University

e.rosenberg@ru.ac.za

Presha Ramsarup

University of the Witwatersand

presha.ramsarup@,wits.ac.za

Sibusisiwe Gumede

Rhodes University

mumzo.g@gmail.com

Heila Lotz-Sisitka

Rhodes University

$\underline{\text { h.lotz-sisitka@,ru.ac.za }}$ 